\title{
Acute responses of iron indices in Quarter Horses during a 3-barrel racing exercise
}

\author{
Clarisse S. Coelho ${ }^{1}$, Mario Cappi Neto ${ }^{2}$, Marcela B. Binda ${ }^{2}$, Fernanda A. Teixeira ${ }^{2}$, \\ Renan S. Carvalho ${ }^{2}$ Laís P. Macedo ${ }^{2}$, Hélio C. Manso Filho ${ }^{3}$ \\ ${ }^{1}$ Federal University of Bahia (UFBA), Veterinary Medicine School (EMEVZ), \\ Anatomy, Pathology and Veterinary Clinics Department (DEAPAC), Salvador, BA, Brazil \\ ${ }^{2}$ Vila Velha University (UVV-ES), Veterinary Medicine School, Vila Velha, ES, Brazil \\ ${ }^{3}$ Federal Rural University of Pernambuco (UFRPE), Equine Research Group, Recife, PE, Brazil
}

Received December 3, 2017

Accepted May 15, 2018

\begin{abstract}
Energy metabolism and physical performance are dependent on sufficient iron metabolism. Therefore, studies evaluating the iron profile are necessary to elucidate this trace mineral requirements and its role in the equine exercise physiology. The aim of this study was to evaluate the influence of barrel racing exercise on serum iron profile of Quarter Horses. Twenty-two regularly trained Quarter Horses ( 8 females and 14 males, $4.8 \pm 2.4$ years old, mean body weight $431.7 \pm 33.9 \mathrm{~kg}$ ) were enrolled in this study with the owner's informed consent. All horses were evaluated at T0 (at rest), T1 (immediately after barrel racing trial), T2 (30 min after trial) and T3 ( $2 \mathrm{~h}$ after trial). At these time points, blood samples were taken to determine the packed cell volume (PCV), red blood cell count (RBC), haemoglobin concentration $(\mathrm{Hb})$, total protein $(\mathrm{TP})$, serum iron (SI), total iron-binding capacity (TIBC) and transferrin saturation (TSAT). Variables were analyzed for normality through Kolmogorov-Smirnov test and comparisons were made using Tukey test, considering $P<0.05$. The imposed exercise challenge significantly altered PCV, RBC, haemoglobin concentration, TP, SI and TSAT, with higher values were recorded at T1. These findings can be linked to an increased demand as a result of physical activity. Significant changes occurred in the iron status in physically well-conditioned Quarter Horses during the barrel racing exercise. Better understanding of iron metabolism in horses will help determine the actual necessity of supplementation.
\end{abstract}

Equines, haematology, physical activity

During exercise, electrolytes are involved in several physiological processes (Assenza et al. 2014). In particularly, iron is an essential structural component of haemoglobin (Jackson 1997; Assenza et al. 2014), myoglobin, cytochrome, catalase and peroxidase, and other enzymes involved in energy-generating oxidative processes (Walker et al. 2001; Inoue et al. 2005). Athletic horses have a higher requirement for iron compared to sedentary horses due to a greater synthesis of haemoglobin and myoglobin, and sweat loss (Jackson 1997). Recent study has shown that energy metabolism and physical performance are dependent on sufficient iron metabolism (Buratti et al. 2015).

Generally, iron is the first trace mineral considered by a large majority of trainers and veterinarians in terms of supplementation for racing horses, based on human studies (Carlson 1994). Although rare in horses (Assenza et al. 2016a), iron depletion could lead to a decreased maximum oxygen uptake and reduced capacity of muscles to use oxygen for oxidative production of energy (Portal et al. 2003). However, the optimum level of iron availability in the athletic performance and an athlete's ability to train is still uncertain (Buratti et al. 2015), which shows the importance of evaluating the iron status in athletes. Usually, the assessment of iron status includes the determination of the packed cell volume $(\mathrm{PCV})$, haemoglobin concentration $(\mathrm{Hb})$ and other indices of the red blood

Address for correspondence:

Clarisse S. Coelho

DEAPAC, EMEVZ, UFBA

Avenida Adhemar de Barros, 500 - Ondina

Salvador-BA, CEP: 40170-110, Brazil

Phone: +55 71999452864

Email: clarissecoelho@yahoo.com.br

http://actavet.vfu.cz/ 
cell count (RBC), but more recently, it also can be evaluated through serum iron (SI), iron storage ferritin, transferrin saturation (TSAT) and serum haptoglobin (Wordwood 1997; Assenza et al. 2016a,b).

Some studies have already been performed on athletic horses (Mills et al. 1996; Hyyppä et al. 2002; Inoue et al. 2005; Minini et al. 2013; Abramovitc et al. 2014; Assenza et al. 2016a,b; Piccione et al. 2017), but information regarding the iron metabolism for 3-barrel racing horses managed in hard weather is limited. This special equine discipline is considered a short-term exercise in which the horse expends the maximum anaerobic effort for less than two minutes. The aim of this study was therefore to evaluate the acute responses to the 3-barrel racing exercise in $\mathrm{PCV}, \mathrm{RBC}, \mathrm{Hb}$, total protein, SI, total ironbinding capacity (TIBC) and TSAT in Quarter Horses under tropical conditions. These findings will contribute to a better understanding of the adjustments made by this particular type of exercise regarding iron metabolism, which is crucial to ensure proper management, and contribute to improving the performance and wellbeing of barrel horses working in hard weather.

\section{Materials and Methods}

This research project was approved by the Ethics, Bioethics and Animal Welfare Committee at the University Vila Velha (CEUA - UVV-ES), and recorded under the number 318/2014, approved on July $2^{\text {nd }} 2014$.

Twenty-two Quarter Horses were used, 8 females and 14 males, with a mean weight of $431.7 \pm 33.9 \mathrm{~kg}$ and between 3 and 10 years of age (mean age $4.8 \pm 2.4$ years), all considered healthy in previous physical examinations and blood work. These animals belong to three farms located in Espirito Santo, Brazil (LAT-20.654198, LONG40.498702).

All horses underwent same food and health management. Their diet consisted of Tifton sp. hay and inorganic mineral salt (Essencefós, Nutrimentos Presence, Paulínia, SP, Brazil; containing 2,500 $\mathrm{mg}$ of iron $/ \mathrm{kg}$ of product) ad libitum and commercial feed $(1.2 \mathrm{~kg} / 100 \mathrm{~kg}$ body weight - DoEqui TopQuality, Nutriave Alimentos, Viana, ES, Brazil; with $12 \%$ crude protein, 3,500 kcal energy, containing $75 \mathrm{mg}$ of iron $/ \mathrm{kg}$ of product), divided into three rations daily. Water was always available.

All horses had been performing physical exercises and training for at least six months. This training consisted of 45-60 min of daily exercise, six days/week, divided between warm-ups and performance of the courses at a trot and canter.

The horses performed a 3-barrel racing test, which consists in navigating three barrels distributed along the course in the shortest time possible. The barrels were distributed in a triangular shape, with a distance of $27.5 \mathrm{~m}$ between the first and second barrel, and a distance of $32 \mathrm{~m}$ from the third to the other barrels. Physical activities were performed between 6:00 h and 11:00 h from November to March. Animals were evaluated for three days, seven animals per day and eight on the last day, with local mean temperature records of $29.5^{\circ} \mathrm{C}$ and mean relative humidity of $67.8 \%$, typical of tropical regions. The sand arena was dry during all evaluation days. Three riders with a mean weight of $80 \mathrm{~kg}$ and a mean height of $1.85 \mathrm{~m}$ were used.

During the exercise, horses used a heart monitor with GPS (RS800CX-G3, Polar Electro, Lake Success, NY, USA) in order to record medium HR (HRmed), maximum HR (HRmax), mean velocity (Vmed), maximum velocity (Vmax) and duration of exercise achieved by each animal. Data were analyzed using the ProTrainer 5 program (Polar Electro, Lake Success, NY, USA).

For the present study, animals were evaluated at T0 (before exercise, at rest, inside the box), T1 (immediately after trial), T2 (30 min after trial), and T3 (2 $\mathrm{h}$ after trial).

Blood samples were aseptically obtained via jugular vein puncture using disposable needles $(25 \mathrm{~mm} \times 0.8 \mathrm{~mm})$, with a negative pressure system (4-ml capacity tubes containing K3-EDTA, ethylenediamine tetraacetic acid, for determining PCV, RBC, and haemoglobin concentration; $9 \mathrm{ml}$ capacity tubes without anticoagulant for determination of serum protein, serum iron and total iron-binding capacity). All samples were transported in a cooler with ice to the Clinical Laboratory of the Veterinary Diagnostic Center (CDV, Vitória, ES, Brazil), for immediate processing, with a mean interval of $2 \mathrm{~h}$ between blood collection and laboratory analysis. Samples from the tubes with no anticoagulant were immediately centrifuged for 10 min (Centrifuge Model TDL80-2B, Centribio, Curitiba, PR, Brazil) at 2,000 $\mathrm{g}$ for separation of serum.

The PCV, RBC, and haemoglobin concentration were measured by means of haematology analyzer (Coulter HmX Hematology Analyzer, Beckman Coulter, Brea, CA, USA). Total serum protein (TP), SI and TIBC were measured using commercial kits (Labtest, São Paulo, SP, Brazil), by means of an automatic biochemical analyzer (Labmax Plenno, Labtest, Lagoa Santa, MG, Brazil). Transferrin saturation (TSAT) was measured using the formula (SI/TIBC)*100 (Abramovitc et al. 2014). 
Analyses of results were made using the GraphPad Instat 3.0 statistical program (GraphPad, La Jolla, CA, USA) and the results were expressed as mean \pm SD. Blood data were evaluated for normality using KolmogorovSmirnov test. Analysis of variance for repeated measures (One-way ANOVA) followed by comparison between means (Tukey test) was done to evaluate the possible influence of exercise on the studied variables. Values of $P \leq 0.05$ were considered significant.

\section{Results}

Initial physical examinations during the selection process showed heart rate values of $37.6 \pm 10.0$ beats $/ \mathrm{min}$, with no pathological murmurs, respiratory rate of $21.6 \pm 7.7$ breaths per min, presence of normal bowel sounds, rectal temperature of $37.4 \pm 0.3{ }^{\circ} \mathrm{C}$ and normal mucous membranes. Complete blood counts showed RBC values of $7.63 \pm 0.65 \times 10^{6} / \mu \mathrm{l}$, haemoglobin concentration of $12.55 \pm 1.07 \mathrm{~g} / \mathrm{dl}, \mathrm{PCV}$ of $35.7 \pm 3.4 \%$, and $\mathrm{WBC}$ of $9,331.8 \pm 2,029.6 / \mu 1$.

The ANOVA showed a significant effect of exercise on all variables, except for TIBC (Table 1), with higher values recorded in T1. Table 2 shows the heart rate (HR), velocity, and exercise duration recorded during the heart rate monitoring.

Table 1. Mean vaues ( \pm standard deviation) of the packed cell volume, red blood cell count, haemoglobin concentration, serum protein, serum iron, total iron-binding capacity and transferrin saturation measured in 22 horses during a field 3-barrel exercise.

\begin{tabular}{lrrrrr}
\hline Variable & \multicolumn{4}{c}{ Experimental period } \\
\cline { 2 - 5 } & \multicolumn{1}{c}{ T0 } & \multicolumn{1}{c}{ T1 } & \multicolumn{1}{c}{ T2 } & T3 & \multicolumn{1}{c}{ T2 } \\
\cline { 2 - 5 } PCV $(\%)$ & $35.7 \pm 3.4^{\mathrm{a}}$ & $47.3 \pm 4.3^{\mathrm{b}}$ & $36.1 \pm 3.5^{\mathrm{a}}$ & $35.3 \pm 3.5^{\mathrm{a}}$ & $<0.0001$ \\
$\mathrm{RBC}, \times 10^{6} / \mu \mathrm{l}$ & $7.6 \pm 0.7^{\mathrm{a}}$ & $9.9 \pm 0.7^{\mathrm{b}}$ & $7.7 \pm 0.6^{\mathrm{a}}$ & $7.6 \pm 0.6^{\mathrm{a}}$ & $<0.0001$ \\
Haemoglobin $(\mathrm{g} / \mathrm{dl})$ & $12.6 \pm 1.1^{\mathrm{a}}$ & $16.9 \pm 1.3^{\mathrm{b}}$ & $12.8 \pm 0.9^{\mathrm{a}}$ & $12.6 \pm 1.0^{\mathrm{a}}$ & $<0.0001$ \\
TP $(\mathrm{g} / \mathrm{dl})$ & $6.4 \pm 0.5^{\mathrm{a}}$ & $7.3 \pm 0.6^{\mathrm{b}}$ & $6.3 \pm 0.6^{\mathrm{a}}$ & $6.2 \pm 0.6^{\mathrm{a}}$ & $<0.0001$ \\
$\mathrm{SI}(\mu \mathrm{g} / \mathrm{dl})$ & $172.1 \pm 31.1^{\mathrm{a}}$ & $219.0 \pm 40.7^{\mathrm{b}}$ & $180.0 \pm 28.2^{\mathrm{a}}$ & $181.3 \pm 47.0^{\mathrm{a}}$ & $<0.0001$ \\
TIBC $(\mu \mathrm{g} / \mathrm{dl})$ & $283.0 \pm 50.5^{\mathrm{a}}$ & $292.0 \pm 53.4^{\mathrm{a}}$ & $303.1 \pm 42.2^{\mathrm{a}}$ & $300.3 \pm 48.2^{\mathrm{a}}$ & 0.0642 \\
TSAT $(\%)$ & $61.5 \pm 10.4^{\mathrm{a}}$ & $75.8 \pm 11.6^{\mathrm{b}}$ & $59.4 \pm 5.4^{\mathrm{a}}$ & $60.1 \pm 10.7^{\mathrm{a}}$ & $<0.0001$
\end{tabular}

Different superscripts in the same line denote significant differences by Tukey test $(P \leq 0.05)$; T0: at rest; T1: immediately after the exercise; T2: at 30 min of recovery and T3: at $2 \mathrm{~h}$ of recovery. PCV - packed cell volume; RBC - red blood cell count; TP - total protein; SI - serum iron; TIBC - total iron-binding capacity; TSAT transferrin saturation

Table 2. The heart rate, speed, and exercise duration for 22 Quarter Horses subjected to a field 3-barrel exercise.

\begin{tabular}{lr}
\hline HRmax, beats/min & $191.1 \pm 25.6$ \\
HRmed, beats/min & $154.6 \pm 37.7$ \\
Vmax, m/s & $10.30 \pm 2.11$ \\
Vmed, m/s & $2.28 \pm 0.58$ \\
Exercise duration, sec & $19.58 \pm 2.76$ \\
\hline
\end{tabular}

HRmax - maximum heart rate; HRmed mean heart rate; Vmax - maximum velocity; Vmed - mean velocity

\section{Discussion}

The present project showed that 3-barrel racing produced significant changes in the iron metabolism, similarly to other studies including other equine disciplines (Inoue et al. 2005; Machado et al. 2010; Abramovitc et al. 2014; Assenza et al. 2014; Burlikowska et al. 2015; Assenza et al. 2016b). Values recorded through the experimental period are within the normal range described by Orsini and Divers (2013). However, they were much superior for TSAT. 
Physical exercise affects the iron status of athletes impacting significantly on oxidative metabolism and aerobic performance (Piccione et al. 2017). Possibly, based on this affirmation, iron supplements are largely used in horses, leading more commonly to an overload than to a deficiency (Hyyppä et al. 2002; Machado et al. 2010). In equines, iron losses are much inferior during exercise and spleen, liver and bone marrow reservoirs of iron are much higher than those observed in humans (Jackson 1997). Therefore, studies evaluating iron profile are necessary and important to elucidate this trace mineral requirements and its role on the equine exercise physiology (Piccione et al. 2002). Findings reported in studies of equine athletes are conflicting, and no studies have proven so far that exercise leads to iron deficiency in horses as has been observed in human athletes (Inoue et al. 2005).

It is well known that the type, intensity and duration of exercise, as well as the athletic fitness and training level can influence haematological variables, such as the iron profile, and this can be the main reason for some differences found between Quarter Horses and other researches (Inoue et al. 2002; Fazio et al. 2011; Minini et al. 2013; Abramovitc et al. 2014; Burlikowska et al. 2015; Assenza et al. 2016a). The HRmax observed in the Quarter Horses studied suggested that the imposed exercise was submaximal; superior to that found by Inoue et al. (2002) who reported $182 \pm 3$ beats/min for Thoroughbred horses at the maximum speed, and different from Souza et al. (2017) who reported $\sim 200$ beats/min in Quarter Horses also used for barrel racing. According to Hodgs on et al. (1990), heavily exercised horses reached a HRmax of 220-230 beats/min. The tachycardia observed corroborates several findings reported in literature and is attributed to the increased metabolic requirements of the muscles during exercise and increased sympathetic activity, being correlated with exercise intensity (Munoz et al. 2008; Ferraz et al. 2009).

In this research, a significant rise of $27.3 \%$ was observed for SI in T1. Similar results were described in the jumping horses (Burlikowska et al. 2015; Assenza et al. 2016b; Piccione et al. 2017), Lusitano horses (Minini et al. 2013) and Thoroughbreds (Inoue et al. 2002; Assenza et al. 2016a). Mills et al. (1996) also found elevated SI in racing and endurance horses during the first $24 \mathrm{~h}$ after exercise. An increase in SI with exercise can be attributed to its release from storage cells, such as liver, spleen and reticuloendotelial cells, characterizing it as an acute response to strenuous exercise workload (Minini et al. 2013; Burlikowska et al. 2015; Assenza et al. 2016a; Piccione et al. 2017). When elevated SI is associated with increased TSAT levels as observed in this study and by Assenza et al. (2016a), it can suggest iron mobilization by the reticuloendotelial system to the bone marrow, possibly due to a greater erythropoiesis to increase the number of circulating erythrocytes (Mills et al. 1996; Jackson 1997; Buratti et al. 2015; Burlikowska et al. 2015). However, other authors (Inoue et al. 2002; Inoue et al. 2005; Piccione et al. 2017) noted that the elevation in SI could be attributed to ruptured erythrocytes due to the physical and chemical stress of exercise (Machado et al. 2010), as slow recovery of SI would be more associated with haemolysis or damaged muscular tissue (In oue et al. 2002; Piccione et al. 2017). In this experiment, SI values returned to basal levels with $30 \mathrm{~min}$ of recovery, suggesting that the elevation in SI was not related to haemolysis. Furthermore, a significant elevation of RBC $(\sim 30.3 \%)$ was noticed in $\mathrm{T} 1$, contradicting the haemolysis possibility.

Exercise also caused a significant elevation in the PCV $(\sim 32.5 \%)$ and haemoglobin concentration $(\sim 32.5 \%)$ in Quarter Horses. These findings have already been described as a result of physical activity (Munoz et al. 2008; Ferraz et al. 2009; Assenza et al. 2016a; Binda et al. 2016; Piccione et al. 2017). The temporal increase of these haematological variables occurs due to the possible combination of the movement of blood fluid to tissues and splenic contraction (Inoue et al. 2002), with the last one representing an acute response to effort. A temporal increase of total protein was observed on this experiment, 
and was also described by Minini et al. (2013), characterizing it as an exercise-induced haemoconcentration.

A recent study suggested an increasing role of skeletal muscle in regulation of body iron metabolism during physical exercise (Buratti et al. 2015). According to these authors, generation of reactive oxygen species (ROS) in the contracting skeletal muscle changes the iron status in athletes, even in short-duration, moderate- to high-intensity anaerobic exercises, like the 3-barrel racing.

On the other hand, in contrast to our findings, some authors have reported a reduction in SI after physical exercise in different sports disciplines (Inoue et al. 2002; Abramovitc et al. 2014; Assenza et al. 2014; Kristensen et al. 2014). Despite haemoconcentration, Kristensen et al. (2014) observed a decrease in SI, attributing it to an exercise-induced inflammatory response. Yet, the reduction in SI during exercise occurred due to increased urinary excretion and relative slowness of absorption from the gastrointestinal tract (Assenza et al. 2014) and plasma volume expansion induced by training (Inoue et al. 2005). However, in this last research, a reduction in TIBC and TSAT was also observed, which was not found in the Quarter Horses studied.

All the studied variables returned to basal levels between $30 \mathrm{~min}$ and $2 \mathrm{~h}$ after the end of the physical activity, suggesting that the horses were well-conditioned to the imposed exercise.

The present study demonstrates that significant changes occur in the iron status in physically well-conditioned Quarter Horses during the barrel racing exercise in hard weather conditions. In spite of the changes, no horses needed iron supplementation. Our results reinforce the importance of studying normal haematochemical changes during this type of exercise, such as those observed for the iron profile, under tropical conditions, to properly evaluate the animals' fitness and well-being. Furthermore, better understanding of iron metabolism in horses will help determine the actual necessity of supplementation, which is often used by elite athletes.

\section{Acknowledgements}

The authors thank CAPES for Mario Cappi Neto's Masters Scholarship.

\section{References}

Abramovitc G, Parra AC, Fernandes WR 2014: Variações de níveis séricos de ferro, da capacidade total de ligação do ferro e da saturação de transferrina em equinos de corrida, antes e após exercício físico. Rev Bras Med Vet 36: $289-293$

Assenza A, Bergero D, Congiu F, Tosto F, Giannetto C, Piccione G 2014: Evaluation of serum electrolytes and blood lactate concentration during repeated maximal exercise in horse. J Eq Vet Sci 34: 1175-1180

Assenza A, Casella S, Giannetto C, Fazio F, Tosto F, Piccione G 2016a: Iron profile in Thoroughbreds during a standard training program. Aust Vet J 94: 60-63

Assenza A, Congiu F, Giannetto C, Fazio F, Piccione G 2016b: Serum iron, transferrin and haptoglobin concentration variations during repeated show jumping competition in horse. Acta Vet Brno 85: 343-347

Binda MM, Teixeira FA, Carvalho RS, Macedo LP, Conti LMC, Manso Filho HC, Coelho CS 2016: Effects of 3-barrel racing exercise on electrocardiographic and on blood parameters of Quarter Horses. J Eq Vet Sci 47: $71-76$

Buratti P, Gammella E, Rybinska I, Cairo G, Recalcati S 2015: Recent advances in iron metabolism: relevance for health, exercise, and performance. Med Sci Sports Exerc 47: 1596-1604

Burlikowska K, Boguslawska-Tryk M, Szymeczko R, Piotrowska A 2015: Haematological and biochemical blood parameters in horses used for sport and recreation. J Central Eur Agric 16: 370-382

Carlson GP 1994: Forty years later - can we diagnose and treat anemia yet? Proceedings of the Bain Fallon Memorial Lectures 16: 273-275

Fazio F, Assenza A, Tosto F, Casella S, Piccione G, Caola G 2011: Training and haematochemical profile in Thoroughbreds and Standardbreds: A longitudinal study. Livest Sci 141: 221-226

Ferraz GC, Teixeira Neto AR, D’Angelis FHF, Lacerda Neto JC, Queiroz Neto A 2009: Alterações hematológicas e cardíacas em cavalos árabes submetidos ao teste de esforço crescente em esteira rolante. Braz J Vet Res Anim Sci 46: 431-437 
Hodgson DRR, Rose RJ, Kelso TB, McCutcheon LJ, Bayly WM, Gollnick PD 1990: Respiratory and metabolic responses in the horse during moderate and heavy exercise. Pflügers Arch 417: 73-78

Hyyppä S, Höyhtya M, Nevalainen M, Pösö AR 2002: Effect of exercise on plasma ferritin concentrations: implications for the measurement of iron status. Eq Vet J 34: 186-190

Inoue Y, Matsui A, Asai Y, Aoki F, Matsui T, Yano H 2005: Effect of exercise on iron metabolism in horses. Biol Trace Elem Res 107: 33-42

Inoue Y, Osawa T, Matsui A, Asai Y, Murakami Y, Matsui T, Yano H 2002: Changes of serum mineral concentrations in horses during exercise. Asian-Austr J Anim Sci 15: 531-536

Jackson SG 1997: Trace minerals for the performance horse: known biochemical roles and estimates of requirements. Ir Vet J 50: 668-674

Kristensen L, Buhl R, Nostell K, Bak L, Petersen E, Lindholm M, Jacobsen S 2014: Acute exercise doe not induce an acute phase response (APR) in Standardbred trotters. Can J Vet Res 78: 97-102

Machado LP, Kohayagawa A, Yonezawa LA, Silveira VR, Saito ME 2010: Metabolismo do ferro em equinos atletas. Ciência Rural 40: 703-711

Mills PC, Smith NC, Casas I, Harris P, Harris RC, Marlin DJ 1996: Effects of exercise intensity and environmental stress on indices of oxidative stress and iron homeostasis during exercise in the horse. Eur J Appl Physiol Occup Physiol 74: 60-66

Minini RAB, Laposy CB, Neto HB, Melchert A, Giuffrida R, Rossi H, Valle HFD 2013: Concentrações de ferro, cobre, zinco e manganês em equinos da raça Puro-Sangue Lusitano, antes e após exercício. Pesq Vet Bras 33: 1045-1048

Munoz A, Riber C, Trigo P, Castejon F 2008: Erythrocyte indices in relation to hydration and electrolytes in horses performing exercises of different intensity. Comp Clin Pathol 17: 213-220

Orsini JA, Divers TJ 2013: Reference Values. In: Orsini JA, Divers TJ (Ed): Equine Emergencies: Treatment and Procedures. Saunders, Philadelphia, 799 p.

Piccione G, Rizzo M, Arfuso F, Brunschetta D, Giudice E, Assenza A 2017: Iron metabolism modification during repeated show jumping event in equine athletes. Ann Anim Sci 17: 197-204

Portal S, Epstein M, Dubnov G 2003: Iron deficiency and anemia in female athletes: causes and risks. Harefuah 126: $88-94$

Souza, LA, Hynka MM, Nery PCR, Coelho CS, Manso HECCC, Manso Filho HC 2018: The effect of repeated barrel racing on blood biomarkers and physiological parameters in Quarter horses. Comp Ex Physiol 14: $47-54$

Walker BL, Tiong JW, Jefferies WA 2001: Iron metabolism in mammalian cells. Int Rev Cytol 211: 241-278

Wordwood M 1997: The laboratory assessment of iron status B an update. Clin Chim Acta 259: 3-23 